\title{
PENERAPAN USER EXPERIENCE DESIGN PADA PENGEMBANGAN APLIKASI MOBILE MARKOPI
}

\author{
Riyanthi Angrainy Sianturi ${ }^{* 1}$ \\ ${ }^{1}$ Institut Teknologi Del \\ Email: ${ }^{1}$ riyanthias@gmail.com \\ *Penulis Korespondensi
}

(Naskah masuk: 06 Desember 2019, diterima untuk diterbitkan: 19 Juli 2021)

\begin{abstract}
Abstrak
Penelitian ini bertujuan untuk menerapkan proses User Experience Design (UXD) dalam pengembangan aplikasi mobile dengan studi kasus budidaya kopi. Aplikasi yang dibangun bertujuan untuk menjembatani petani dan fasilitator kopi dalam proses mencari dan berbagi informasi budidaya kopi. Belum terdapat aplikasi yang dapat memfasilitasi petani dalam mendapatkan informasi budidaya kopi yang baik yang memperhatikan aspek experience yang baik. Dalam penerapan UXD ini, peneliti melakukan tahapan proses yang menggabungkan proses umum UXD dengan pengembangan perangkat lunak, yaitu preliminary research, prototyping, user testing, maintenance, pengembangan aplikasi, heuristic evaluation, blackbox testing dan user acceptance test. Keberhasilan pengembangan aplikasi ditentukan oleh proses UXD yang dilakukan terlebih dahulu. Implementasi tidak segera dilakukan sebelum kebutuhan pengguna dapat didefinisikan, sehingga setelah research, prototipe diuji oleh pengguna. Pengembangan aplikasi dilakukan setelah pengguna menyetujui rancangan yang diukur melalui USE Questionnaire. Aplikasi berbasis Android yang dibangun mengakomodir informasi cara budidaya kopi mulai dari penanaman, pemupukan, sanitasi kebun dan pembibitan. Fasilitator dapat menambahkan informasi pada aplikasi, sedangkan pengguna hanya dapat membaca informasi yang tersedia. Dari proses penelitian yang dilakukan disimpulkan bahwa aplikasi yang dibangun memenuhi kebutuhan pengguna berdasarkan fungsi yang disediakan di dalam aplikasi dan kemudahan serta kepuasan penggunaan, yang diukur melalui User Acceptance Test. Tahapan-tahapan yang dilakukan peneliti dapat dijadikan acuan dalam pengembangan aplikasi yang memenuhi User Experience yang baik.
\end{abstract}

Kata Kunci: User Experience, User Experience Design (UXD), User Testing, Kopi

\section{APPLYING USER EXPERIENCE DESIGN IN MARKOPI MOBILE APPLICATION DEVELOPMENT}

\begin{abstract}
This research aims to apply the User Experience Design (UXD) process in developing mobile applications for coffee farming. The application built to bridge the coffee farmers and facilitators in the process of finding and sharing the informations. There is no application that can facilitate farmers in getting good coffee farming information, and also concern about good user experience. For applying UXD process, researchers combines the general process of UXD with software development process, namely preliminary research, prototyping, user testing, maintenance, application development, heuristic evaluation, blackbox testing and user acceptance test. The success of application development is determined by the UXD process that was carried out first. Implementation is not immediately carried out before user needs was defined, so after the research stage, prototype is tested by the user. Application development is done after the user agrees the prototype design, which measured through the USE Questionnaire. Android-based applications are built to accommodate information on coffee farming from planting, fertilizing, sanitation gardens and nurseries. The facilitator can add information to the application, while the user can only read the information available. From the research process it was concluded that the application built meets user needs based on the functions provided in the application and the ease and satisfaction of use, as measured through the User Acceptance Test. Stages by the researcher can be used as a reference in developing applications that meet a good User Experience.
\end{abstract}

Keyword: User Experience, User Experience Design (UXD), Usability Testing, User Testing, Coffee 


\section{PENDAHULUAN}

Penggunaan teknologi saat ini sangat besar dan memiliki karakteristik yang beragam. Karakteristik yang beragam tersebut memiliki ciri khas yang dapat dibedakan menurut faktor-faktor terkait demografi (misalnya jenis kelamin, profesi, dan wilayah geografis), tingkat pengetahuan, keterampilan individu, budaya, serta kepribadian. Keragaman latar belakang dan karakteristik pengguna tersebut mempengaruhi terbentuknya pengalaman personal setiap individu. Studi tentang pengalaman pengguna merupakan isu penting di bidang design industry dan pengembangan sistem (Bounchard dan BongardBlanchy, 2015). User Experience atau pengalaman pengguna adalah efek yang dirasakan oleh pengguna sebagai hasil dari interaksi dengan sistem atau produk yang termasuk pengaruh dari usability, usefulness, dan emotional impact selama interaksi (Hartson \& Pyla, 2012).

Saat ini banyak aplikasi yang sudah memperhatikan aspek User Experience seperti Snapchat, Google Wallet, Netflix, Starbuck App, dan lain sebagainya. Untuk aplikasi terkait kopi contohnya adalah aplikasi Starbucks dan Blue Bottle Coffee. Pada kedua aplikasi dapat dirasakan kemudahan dalam akses dan menemukan informasi. Kemajuan teknologi harus dapat dirasakan pada semua aspek termasuk dalam perkembangan kopi saat ini. Kopi adalah salah satu komoditas terpenting dalam perdagangan internasional (Gregory dan Featherstone, 2008).

Salah satu faktor yang mempengaruhi produksi kopi adalah penerapan teknik budidaya tanaman kopi. Pada dasarnya para petani kopi telah memiliki pengetahuan mengenai budidaya kopi yang terbentuk secara turun-temurun dari nenek moyang mereka dan berkembang seiring berjalannya waktu. Namun, tingkat adopsi informasi dan inovasi petani kopi dalam pengembangannya masih tergolong rendah, sehingga petani belum mampu untuk menghasilkan kualitas dan kuantitas kopi yang baik. Selain karena sedikitnya informasi, juga perlu pendampingan, tetapi fasilitator pertanian tidak selalu bisa bersama dengan petani. Oleh karena itu, diperlukan media yang dapat memfasilitasi petani dan fasilitator dalam bertukar informasi. Dengan kemajuan teknologi, satu aplikasi dimungkinkan menjawab permasalahan ini.

Pada aplikasi yang akan dibangun, peran pengguna sangat dibutuhkan untuk memastikan kebutuhannya terpenuhi. Peran pengguna diperlukan pada tahap pengumpulan kebutuhan, pengembangan prototipe dan pengujian. Keterlibatan dalam tahaptahap ini akan memperkecil kemungkinan aplikasi yang dibangun tidak sesuai dengan kebutuhan.

Tujuan penelitian ini adalah untuk menerapkan proses User Experience Design (UXD) dalam pengembangan aplikasi mobile Markopi. Yang menjadi lingkup penelitian adalah pelaksanaan wawancara, observasi, survey dan testing dilakukan dilakukan di kabupaten Toba.

\section{METODE PENELITIAN}

Terdapat empat proses yang digunakan dalam penerapan User Experience Design (UXD) meliputi preliminary research, prototyping, user testing dan maintenance (Getto, 2015). Penelitian ini adalah pengembangan dari empat proses UXD oleh Getto dengan penggabungan dengan proses pengembangan perangkat lunak. Oleh karena itu, proses penelitian mencakup perumusan masalah, preliminary research, prototyping, user testing, maintenance, pengembangan aplikasi, heuristic evaluation, blackbox testing dan user acceptance testing. Tahapan penelitian ditunjukkan pada Gambar 2.

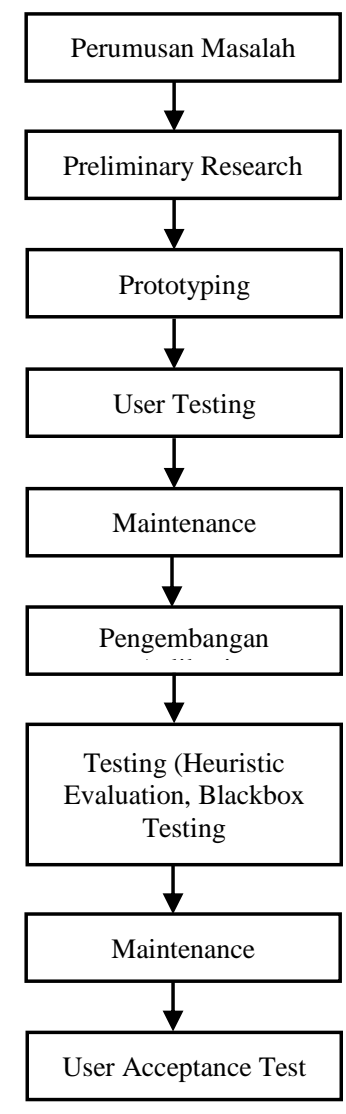

Gambar 1. Metode Penelitian

Tahapan-tahapan pada Gambar 1 dijalankan sebagai berikut.

1. Tahap pertama adalah perumusan masalah.

2. Tahap kedua adalah preliminary research untuk menghasilkan user persona, user stories dan user scenario. Persona merupakan cerita singkat tentang tujuan pengguna, perilaku dan kendala atau frustasi yang dihadapinya. Persona menceritakan apa yang dilakukan, mengapa dilakukan dan apa yang diharapkan pengguna dari sebuah produk. Informasi pada Persona adalah demografi, personality dan hubungan dengan produk; minimum mengandung foto, 
nama, umur, lokasi, pekerjaan dan biografi. User Stories adalah deskripsi sederhana dan singkat terkait fitur yang diharapkan dari perspektif orang yang menginginkannya, misalnya pengguna sebuah aplikasi. User Stories terdiri dari 3 bagian kalimat: As a... (sebutkan profesi), I want to... (apa yang dibutuhkan), So that... (tujuan akhir yang ingin dicapai). User Scenario adalah cerita tentang situasi pengguna pada User Stories, mencakup user + kegiatan + environment. Tujuan User Scenario adalah membantu untuk lebih berempati pada pengguna, bisa memahami dan merasakan yang dialami pengguna. Scenario ini dibuat dengan menambahkan pada bagian akhir satu User Stories (Unger \& Chandler, 2012).

3. Tahap ketiga adalah prototyping, kegiatannya merancang hasil preliminary research.

4. Tahap keempat adalah user testing, melakukan pengujian tehadap hasil rancangan yang telah dibuat sebelumnya. Pengujian dilakukan oleh pengguna yang telah ditentukan.

5. Tahap kelima adalah maintenance berupa perbaikan prototipe berdasarkan hasil pengujian yang dilakukan pengguna dan ahli. Hasilnya adalah prototipe yang telah diperbaiki.

6. Tahapan keenam adalah proses pengembangan aplikasi.

7. Tahap ketujuh adalah pengujian terhadap aplikasi yang sudah dibangun. Pengujian dilakukan dengan Heuristic Evaluation, yaitu inspeksi terhadap aplikasi yang dilakukan oleh usability expert. Terdapat satu pengujian yang dilakukan oleh peneliti yaitu blackbox testing, tujuannya adalah menguji fungsionalitasi aplikasi.

8. Tahap kedelapan adalah perbaikan (maintenance) aplikasi dari hasil pengujian.

9. Pada tahap akhir kesembilan, dilakukan user acceptance test untuk pemeriksaan kelengkapan dan kesesuaian fungsi-fungsi yang telah dibangun.

\section{TINJAUAN PUSTAKA}

\subsection{User Experience}

Pada tahun 1990-an, istilah User Experience mulai diperkenalkan oleh Donald Norman, dimana dengan perkembangan teknologi saat ini interaksi antara manusia dengan komputer sudah terjadi untuk semua bidang aktivitas manusia. Hal ini yang menyebabkan User Experience harus lebih kaya, lebih efisien, lebih efektivitas dan terdapat kepuasan subjektif. User experience (UX) adalah efek yang dirasakan oleh pengguna sebagai hasil dari interaksi dengan sistem atau produk yang termasuk pengaruh dari usability, usefulness, dan emotional impact selama interaksi (Hartson dan Pyla, 2012). Berdasarkan Interaction Design Foundation (2002), User Experience sederhananya adalah bagaimana perasaan setiap orang ketika mereka menggunakan sebuah produk atau layanan.

\subsection{User Experience Design (UXD)}

UXD adalah peningkatan kepuasan pengguna dengan meningkatkan kegunaan dan konsep yang terkait dengan interaksi antara pengguna manusia dan komputer (Orlova, 2016). Untuk memperoleh User Experience yang baik, maka aplikasi harus mudah ditemukan dan digunakan saat pertama kali sehingga menciptakan perasaan senang saat menggunakan. Aplikasi haruslah mudah digunakan untuk menyelesaikan atau melakukan hal-hal yang diinginkan oleh pengguna. Terdapat tahapan yang dilakukan dalam menerapkan UXD (Getto, 2015), yaitu:

\section{Preliminary Research/User Research}

Preliminary Research/ User Research adalah tahap yang sangat penting dimana tahap ini merupakan tahap untuk mengumpulkan informasi atau kebutuhan yang diperlukan untuk proyek atau perencanaan pembangunan proyek dan bagaimana stakeholder akan bekerja dalam proyek.

\section{Prototyping}

Prototyping merupakan tahap membuat simulasi dari produk akhir yang dihasilkan. Tujuan utama dari tahap prototyping ini adalah untuk menguji apakah alur penggunaan dari produk sudah baik dan konsisten. Prototipe harus mampu membuat stakeholder dan pengguna mengerti dengan jelas bagaimana mereka mampu berinteraksi dengan produk akhir nantinya. Tahap prototyping ini akan menghasilkan mockup yang memungkinkan user untuk melakukan interaksi dengan prototipe seperti layaknya pengguna berinteraksi dengan produk. Tahap prototyping dapat dilakukan dengan beberapa metode yaitu whiteboarding, pencil-and-paper sketching, storyboarding, cardboard cut-outs, dan lainnya.

3. User Testing

User Testing merupakan tahap melakukan pengujian terhadap kebergunaan produk, apakah produk sudah efektif dalam membantu pengguna mencapai tujuan mereka. Usability testing merupakan metode pengujian yang digunakan dalam tahap ini. Tahapan user testing terbagi menjadi dua, yaitu before testing dan after testing. Before testing adalah proses untuk mempersiapkan kebutuhan pengujian mulai dari desain pertanyaan, teknik pengujian kelayakan pertanyaan, sampai dengan teknik analisa data. After testing adalah proses untuk melakukan peningkatan terhadap produk berdasarkan hasil pengujian yang telah dilakukan oleh pengguna.

\section{Maintenance}

Maintenance merupakan tahap yang dilakukan setelah produk yang dihasilkan di-deploy dan digunakan oleh pengguna. Tahap ini berfokus pada perbaikan yang akan dilakukan terhadap produk yang telah dirilis berdasarkan masalah 
yang dialami oleh pengguna saat menggunakan produk.

\subsection{Faktor User Experience}

Terdapat 7 faktor yang mempengaruhi User Experience yang digambarkan seperti sebuah sarang madu (honeycomb) (Peter Morville, 2004) seperti pada Gambar 2.

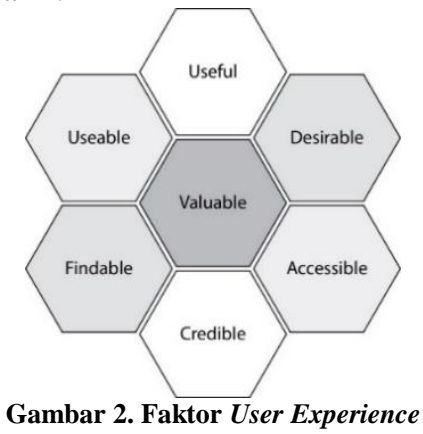

\section{Useful}

Produk yang dihasilkan harus bisa memenuhi kebutuhan pengguna. Produk tersebut tidak akan digunakan apabila tidak bisa mengisi kebutuhan pengguna. Salah satu contohnya adalah aplikasi Amazon. Amazon hanya memberikan ulasan produk yang bermanfaat bagi pelanggan mereka. User memberikan rating (peringkat) terhadap ulasan yang diberikan oleh pengguna lain, apakah ulasan tersebut membantu atau tidak. Amazon kemudian memberi peringkat ulasan berdasarkan bantuan dari para user tersebut. Hal ini berguna bagi pelanggan agar terhindar dari informasi yang tidak relevan sehingga pelanggan dapat berfokus pada ulasan produk yang bermanfaat (Userlytics Corporation).

\section{Usable}

Produk yang dihasilkan harus simpel dan mudah digunakan agar pengguna dapat dengan efektif dan efisien menggunakannya. Selain itu, desain yang dibuat juga harus familiar dan mudah dipahami. Hardgraft adalah salah satu contohnya. Hardgraft membuat website untuk halaman produk mereka yang sangat mudah untuk digunakan. Halaman produk yang dibuat seluruhnya berisi gambar yang membuat pengguna cukup mengklik gambar untuk melihat produk tersebut lebih detail (Userlytics Corporation).

\section{Findable}

Produk yang dihasilkan harus dapat membantu user untuk menemukan sesuatu yang diinginkan dengan mudah. Contohnya adalah Yelp, aplikasi yang bertujuan untuk memberikan kemudahan dalam mencari lokasi suatu tempat berdasarkan lokasi pengguna saat ini seperti restoran, gym, bar, bengkel, dll. Aplikasi ini menyediakan detail dari sebuah tempat dan ulasan mengenai tempat tersebut dari orang-orang yang pernah mengunjunginya (Userlytics Corporation).

\section{Desirable}

Produk yang dihasilkan harus memiliki tampilan visual yang menarik agar dapat membangkitkan emosi dari pengguna untuk membuat produk tersebut semakin diinginkan. Apple adalah contoh yang tepat untuk ini. Desain, gambar, bentuk ramping dan elegan menarik orang-orang yang menginginkan gaya hidup yang mengandung karakteristik tersebut (Userlytics Corporation).

\section{Credible}

Produk atau layanan yang diberikan harus dapat dipercaya oleh pengguna. Produk yang telah dihasilkan harus akurat dan sesuai tujuan. Contohnya adalah Fit2Fat2Fat, yang merupakan salah satu program transformasi berat badan. Drew Manning membagikan pengalamannya sendiri dalam proses penurunan berat badan dengan gambar dan buku yang memotivasi untuk membuat pengguna percaya dan yakin terhadap programnya (Userlytics Corporation).

6. Accessible

Produk yang dihasilkan harus dapat dirasakan oleh semua orang dengan pengalaman yang sama dengan orang lain, bahkan termasuk orang yang menyandang disabilitas. Lookout adalah contohnya, yaitu sebuah aplikasi android yang dirancang untuk membantu orang buta atau tuna netra untuk mendapat lebih banyak kebebasan dengan memberikan isyarat pendengaran tentang objek, teks, dan orang-orang di sekitar mereka. Aplikasi ini juga dapat digunakan tanpa koneksi internet (Userlytics Corporation).

\section{Valuable}

Produk atau layanan yang harus dapat memberikan sebuah nilai yang berpengaruh terhadap pengguna. Whisky Exchange adalah website yang menyediakan gambar dan deskripsi mengenai wiski secara detail sebelum pelanggan membeli wiski. Website tersebut memberikan informasi yang tidak dapat ditemukan di tempat lain (Userlytics Corporation).

\section{PELAKSANAAN PENELITIAN}

Pada bab ini dibahas tentang pelaksanaan penelitian dengan tahapan-tahapan pada Gambar 1 .

\subsection{Preliminary Research}

Pada tahap ini, peneliti menggunakan teknik user interviews, dan surveys dalam memperoleh 
informasi yang dibutuhkan. Peneliti mendatangi pengguna yang menjadi target di tempat mereka bekerja yaitu di perkebunan kopi dan rumah pengolahan biji kopi setelah panen. Kegiatan ini memberi gambaran bagi peneliti tentang tugas-tugas yang dilakukan oleh pengguna secara langsung karena dilakukan di lingkungan mereka. Setelah tahap ini dilakukan, membuat user persona, user stories, user scenario, dan user flows.

Kegiatan research terhadap pengguna adalah bagian yang sangat penting dalam proses User Experience Design (UXD). Alasan pentingnya research adalah keterlibatan pengguna sejak awal dan pencarian kebutuhan pengguna di awal proses meningkatkan kemungkinan aplikasi yang dibangun memenuhi kebutuhan pengguna. Kebutuhan ini tidak ditemukan jika peneliti tidak mengetahui kondisi pengguna dan lingkungannya, motivasi dan masalah yang dihadapi.

Sesuai dengan kebutuhannya, pengguna pada penelitian ini dibagi menjadi dua kelompok yaitu fasilitator dan petani kopi. Hasil dari preliminary research adalah sebagai berikut.

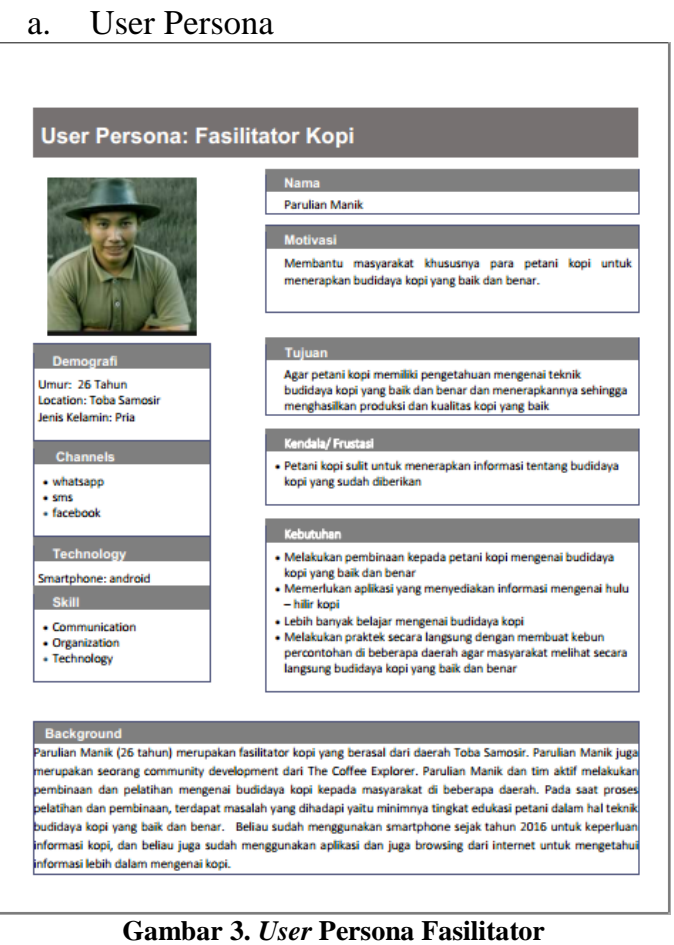

Pada Gambar 3 dan Gambar 4 terdapat data fasilitator dan petani yang sudah diperoleh oleh peneliti. Data tersebut berupa demografi, teknologi yang digunakan, keahlian yang dimiliki, motivasi, tujuan, kendala/ frustasi, kebutuhan, dan background dari fasilitator. Data tersebut merupakan data awal yang harus diperoleh oleh peneliti untuk masuk ke tahap prototyping.

\section{b. User Stories dan User Scenario}

Hasil user stories dan user scenario yang diperoleh peneliti dari pengguna yaitu:

- Petani Kopi
I want to: Mengetahui informasi mengenai budidaya dan pemasaran kopi.

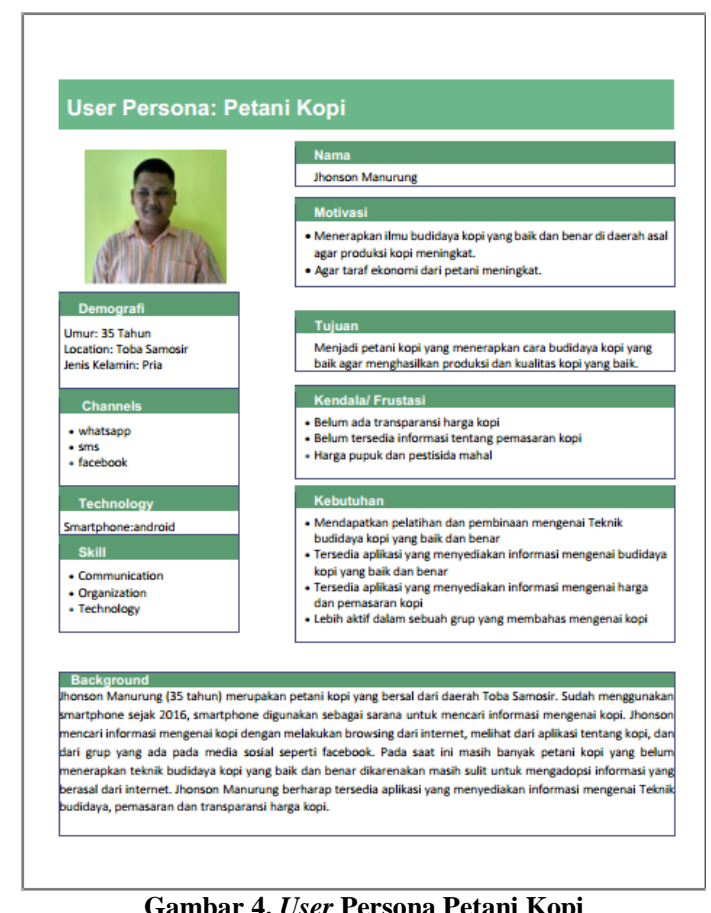

So that: Saya dapat membudidayakan kopi dengan baik dan benar serta dapat memasarkan kopi sendiri.

Scenario: Saya memiliki kopi seluas 10 ha. Saya mengelola lahan tersebut dari mulai proses penanaman hingga panen. Saat panen, kopi akan diolah apakah itu menjadi biji kering, green bean, sampai bubuk kopi. Saya ingin menjual kopi sendiri dalam bentuk apapun tetapi saya tidak memiliki pasar untuk menjual kopi tersebut.

- Fasilitator

I want to: Mengetahui dan bisa berbagi teknik budidaya kopi yang baik dan benar.

So that: Saya bisa membantu petani dalam hal edukasi tentang teknik budidaya kopi.

Scenario: Saya adalah seorang fasilitator dan saya sering mengunjungi petani kopi di berbagai daerah untuk berbagi ilmu tentang budidaya kopi yang baik dan benar. Berdasarkan pengalaman saya, masih belum banyak petani kopi yang menerapkan teknik budidaya yang baik dan benar. Jadi saya ingin membagi ilmu yang saya miliki kepaa masyarakat luas yang membutuhkan yang tidak dapat saya jangkau satu persatu daerah mereka.

\subsection{Prototyping}

Prototyping dapat dilakukan setelah peneliti mendapatkan apa yang dibutuhkan oleh pengguna 
yaitu fasilitator dan petani kopi. Pada tahap ini, peneliti telah merangkum segala kebutuhan pengguna sesuai hasil dari preliminary research. Peneliti merancang aplikasi tentang kopi sesuai dengan kebutuhan pengguna (fasilitator dan petani kopi). Kebutuhan tersebut dinyatakan dalam user persona, yaitu perlunya fasilitas untuk penyediaan informasi budidaya kopi sehingga petani kopi dapat menghasilkan kopi berkualitas. Informasi budidaya disajikan sesuai dengan tahapan-tahapan pertanian kopi dan isinya berupa teks dan gambar.

Untuk memenuhi kebutuhan pengguna, maka peneliti membuat rancangan dalam bentuk prototipe berupa halaman Splashsceen, Home, Navigasi, Submenu, Detail Informasi, Registe dan Login. Spashscreen sebagai halaman pembuka yang mengarahkan pengguna secara otomatis masuk ke halaman Home. Pada halaman Home terdapat pilihan menu yang berisi beberapa submenu. Setelah Submenu, pengguna dapat membaca Detail Informasi. Fitur Registrasi dan Login berkaitan dengan akses ke dalam aplikasi untuk dapat melakukan pengisian informasi. Beberapa halaman hasil prototyping adalah sebagai berikut.

a. Halaman Home

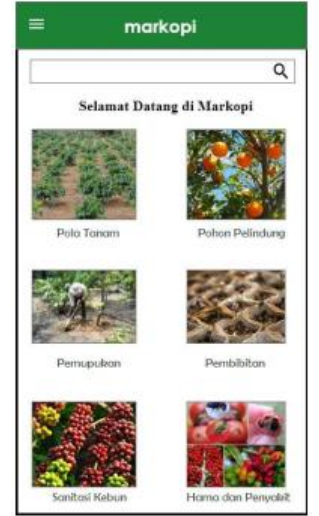

Gambar 5. Halaman Home

Gambar 5 merupakan Home dari aplikasi markopi.

b. Navigasi

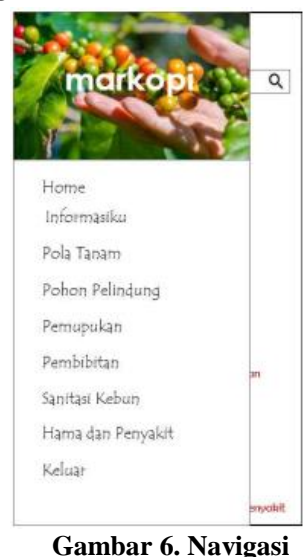

Gambar 6 merupakan tampilan navigasi aplikasi yang terdiri dari menu yang terdapat pada aplikasi. c. Halaman Submenu

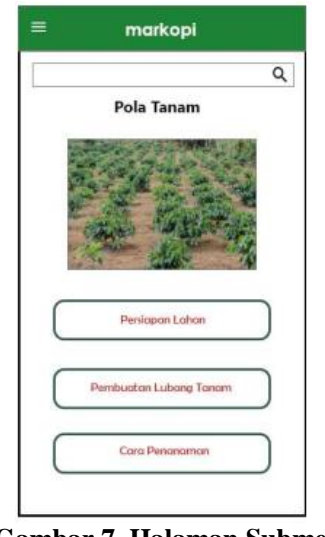

Gambar 7. Halaman Submenu

Gambar 7 merupakan halaman submenu aplikasi.

\section{d. Halaman Detail Informasi}

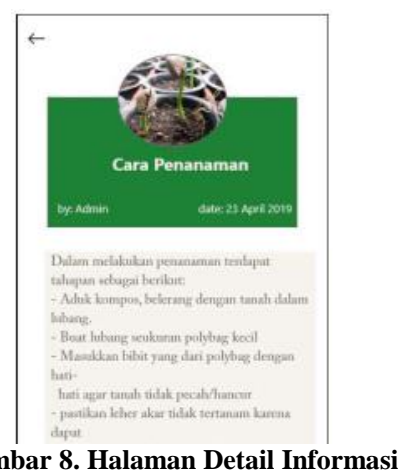

Gambar 8 merupakan halaman detail informasi, jika pengguna mengklik submenu akan tampil halaman tersebut.

\subsection{User Testing}

Pengujian dilakukan oleh perwakilan pengguna untuk menguji hasil dari prototipe yang sudah dirancang. Metode yang digunakan adalah usability testing. Penguji dalam usability testing ini adalah petani dan fasilitator kopi. Responden yang terlibat adalah 5 petani kopi dan 3 fasilitator. Usability testing dilakukan dengan cara pengguna menggunakan aplikasi, peneliti mengamati pengguna bekerja dan selanjutnya pengguna mengisi kuesioner untuk mengukur beberapa faktor. Faktorfaktor pengukur ini mengacu pada faktor yang mempengaruhi User Experience.

Kuesioner usability testing yang digunakan adalah USE Questionnaire karena kemudahan dalam pengaplikasian untuk produk perangkat lunak. Kuesioner mengukur beberapa faktor usability, yaitu usefulness, ease of use, ease of learning, dan satisfaction. Usefulness berkaitan dengan performansi dan daya guna aplikasi dalam memenuhi kebutuhan pengguna. Ease of use berkaitan dengan kemudahan penggunaan aplikasi tanpa banyak instruksi, kemudahan memperbaiki kesalahan dan user friendly. Ease of learning berkaitan dengan kecepatan belajar untuk dapat menggunakan aplikasi; semakin cepat makan 
semakin baik. Satisfaction terkait dengan kepuasan yang dirasakan pengguna yang terlihat dari kesenangan menggunakan, memberikan rekomendasi kepada orang lain dan fungsi berjalan sesuai yang diharapkan user (Hartson \& Pyla, 2012). Kuesioner dapat dilihat pada Tabel 1.

Tabel 1. Rancangan Kuesioner

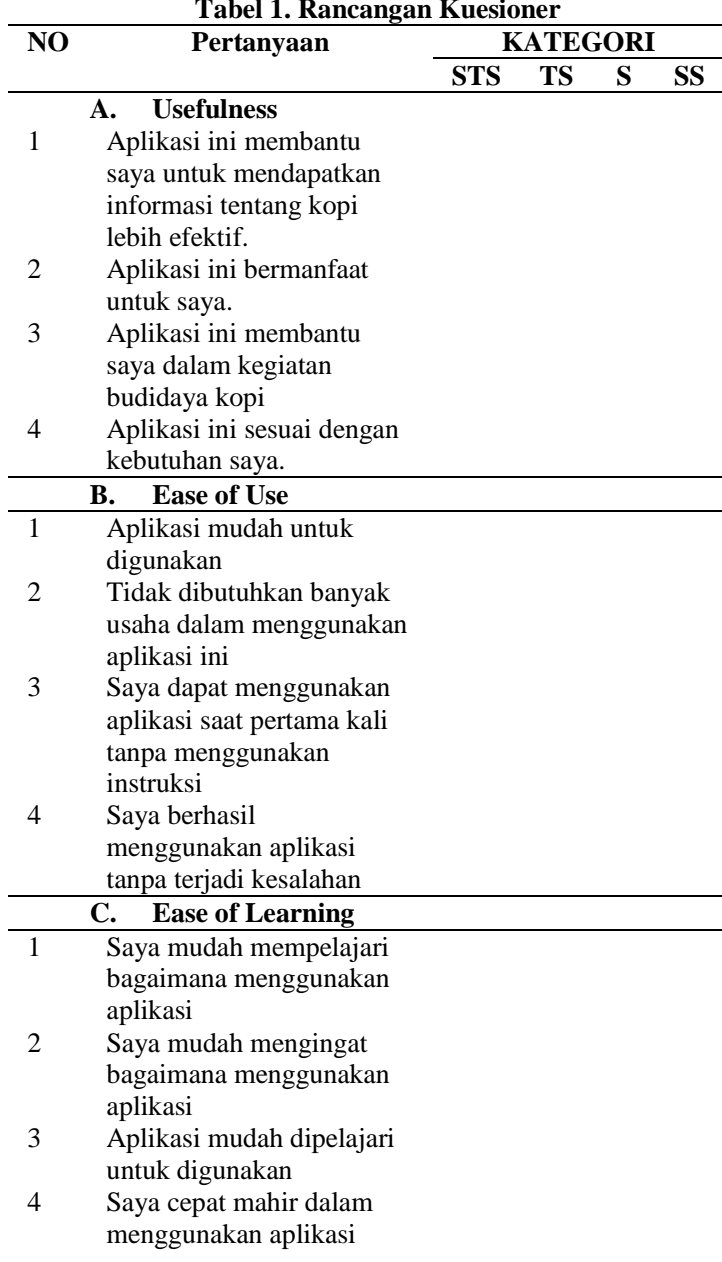

\begin{tabular}{ll}
\hline \multicolumn{1}{c}{ D. $\quad$ Satisfaction } \\
\hline 1 & $\begin{array}{l}\text { Saya merasa puas ketika } \\
\text { menggunakan aplikasi ini }\end{array}$ \\
2 & $\begin{array}{l}\text { Saya akan } \\
\text { merekomendasikan } \\
\text { aplikasi ini kepada teman } \\
\text { saya. }\end{array}$ \\
& $\begin{array}{l}\text { Saya merasa harus } \\
\text { menggunakan aplikasi ini }\end{array}$ \\
& $\begin{array}{l}\text { Saya merasa puas dengan } \\
\text { aplikasi ini sehingga saya } \\
\text { harus memiliki aplikasi ini. }\end{array}$ \\
& Pengukuran
\end{tabular}

Pengukuran usability dilakukan dengan menghitung Grand Mean (GM) pada setiap aspek usability yang digunakan. Penegukuran dilakukan dengan skala Likert. Melalui skala ini, pengguna akan menyatakan persetujuan atau ketidaksetujuan terhadap sejumlah pernyataan terkait obyek yang dinilai (Sugiyono, 2010). Kuesioner menyajikan empat pilihan jawaban terhadap setiap pertanyaan. Pilihan jawaban yang disediakan adalah Sangat Tidak Setuju (STS), Tidak Setuju (TS), Setuju (S) dan Setuju (SS). Skala Likert pada setiap pertanyaan akan diberikan nilai mean, yaitu $\mathrm{SS}=4, \mathrm{~S}=3, \mathrm{TS}=2$, $\mathrm{STS}=1$. Apabila responden dengan jumlah terbanyak memilih sangat setuju maka mean akan mendekati angka 4, dan sebaliknya apabila responden dengan jumlah terbanyak memilih sangat tidak setuju maka mean akan mendekati angka 1 .

Hasil dari pengukuran yang telah dilakukan dapat dilihat pada Tabel 2.

Tabel 2. Hasil Pengujian Usability Testing

\begin{tabular}{|c|c|c|c|c|c|c|c|c|c|c|c|c|c|c|c|c|}
\hline \multirow{3}{*}{$\begin{array}{l}\mathbf{N} \\
\mathbf{0}\end{array}$} & \multicolumn{16}{|c|}{ Jawaban Pertanyaan Ke } \\
\hline & \multicolumn{4}{|c|}{ Usefulness } & \multicolumn{8}{|c|}{$\begin{array}{cc} & \text { Ease of } \\
\text { Ease of Use } & \text { Learning }\end{array}$} & \multicolumn{4}{|c|}{ Satisfaction } \\
\hline & 1 & 2 & 3 & 4 & 1 & 2 & 3 & 4 & 1 & 2 & 3 & 4 & 1 & 2 & 3 & 4 \\
\hline 1 & 3 & 3 & 4 & 4 & 4 & 4 & 4 & 3 & 4 & 4 & 4 & 4 & 3 & 4 & 4 & 3 \\
\hline 2 & 4 & 4 & 3 & 3 & 4 & 4 & 3 & 3 & 3 & 3 & 4 & 3 & 4 & 4 & 4 & 4 \\
\hline 3 & 3 & 3 & 4 & 3 & 4 & 4 & 2 & 2 & 2 & 3 & 3 & 3 & 4 & 3 & 3 & 3 \\
\hline 4 & 3 & 3 & 4 & 3 & 3 & 3 & 2 & 2 & 3 & 3 & 3 & 3 & 3 & 3 & 3 & 3 \\
\hline 5 & 4 & 4 & 3 & 3 & 4 & 4 & 4 & 3 & 4 & 4 & 3 & 3 & 4 & 4 & 4 & 4 \\
\hline$\sum$ & 1 & 1 & 1 & 1 & 1 & 1 & 1 & 1 & 1 & 1 & 1 & 1 & 1 & 1 & 1 & 1 \\
\hline \multirow[t]{3}{*}{$\mathbf{X}$} & 7 & 7 & 8 & 6 & 9 & 9 & 5 & 3 & 6 & 7 & 7 & 6 & 8 & 8 & 8 & 7 \\
\hline & 3 & 3 & 3 & 3 & 3 & 3 & & 2 & 3 & 3 & 3 & 3 & 3 & 3 & 3 & 3 \\
\hline & , & , & , & , & , & , & & , & , & , & , & , & , & , & , & , \\
\hline M & 4 & 4 & 6 & 2 & 8 & 8 & 3 & 6 & 2 & 4 & 4 & 2 & 6 & 6 & 6 & 4 \\
\hline $\begin{array}{l}G \\
M\end{array}$ & & \multicolumn{3}{|c|}{3,4} & \multicolumn{4}{|c|}{$\mathbf{3 , 3}$} & \multicolumn{4}{|c|}{3,3} & \multicolumn{4}{|c|}{3,55} \\
\hline
\end{tabular}

Hasil pengukuran untuk aspek usefulness adalah 3,4 dan masuk ke dalam interval 3,26 - 4,00 yang berarti user sangat setuju bahwa prototipe memiliki tingkat usefulness yang baik. Aspek ease of use dengan nilai 3,3 dan masuk ke dalam interval 3,26 4,00 yang berarti pengguna sangat setuju bahwa prototipe memiliki tingkat ease of use yang baik. Aspek ease of learning dengan nilai 3,3 dan masuk ke dalam interval 3,26 - 4,00 yang berarti pengguna sangat setuju bahwa prototipe memiliki tingkat ease of learning yang baik. Aspek satisfaction dengan nilai 3,55 dan masuk ke dalam interval 3,26 - 4,00 yang berarti pengguna sangat setuju bahwa prototipe memiliki tingkat satisfaction yang baik.

Hasil pengujian ini menjadi acuan peneliti untuk melakukan perbaikan prototipe. Setelah prototipe diperbaiki, maka penelitian melajutkan proses pada pengembangan aplikasi.

\subsection{Pengembangan Aplikasi}

Aplikasi dikembangkan berbasis mobile dengan sistem operasi Android. Pengembangan mengacu pada prototipe yang sudah diuji dan disempurnakan. Setelah selesai dibangun, dilakukan pengujian terhadap aplikasi.

\subsection{Testing}

Terdapat dua pengujian yang dilakukan pada aplikasi yang telah dibangun, yaitu Heuristic Evaluation dan Blackbox Testing. 


\section{a. Heuristic Evaluation}

Heuristic Evaluation (HE) dilaksanakan oleh usability expert yaitu Riyanthi Sianturi. Usability expert memiliki keahlian dalam bidang usability dan perancangan UI. Tugas expert dalam Heuristic Evaluation adalah melakukan inspeksi terhadap masalah usability. Expert menggunakan 10 Usability Heuristic dari Jakob Nielsen sebagai guideline yang digunakan dalam inspeksi terhadap aplikasi. 10 Usability Heuristic terdiri dari: visibility of system status; match between system and the real world; user control and freedom; consistency and standards; error prevention; recognition rather than recall; flexibility and efficiency of use; aesthetic and minimalist design; help users recognize, diagnose and recover from errors; help and documentation (Barnum, 2011). Setiap masalah yang ditemukan, dipetakan pada salah satu dari 10 guideline dan kemudian diberi rating 1-4. Rating 1 (cosmetic) berarti masalah yang tidak terlalu mempengaruhi pengguna; Rating 2 (minor) berarti ada potensi pengguna mengalami kesulitan sehingga dibutuhkan perbaikan dengan tingkat prioritas rendah; Rating 3 (major) berarti ditemukan masalah yang mengganggu dan perlu perbaikan dengan prioritas tinggi; Rating 4 (catasthrope) artinya kesalahan fatal dan wajib dilakukan perbaikan.

Hasil Heuristic Evaluation dijabarkan sebagai berikut.

- Pada fitur menu, prinsip accessibility, rating 3, temuan masalah yaitu Pilihan menu "Pola Tanam" hingga "Pembibitan" yang merupakan menu-menu utama aplikasi, hanya muncul di halaman depan aplikasi, tidak terdapat pada navigasi menu (hanya ada Beranda, Masuk dan Daftar). Hal ini menghalangi kemudahan akses menu dengan beberapa alternatif cara.

- Pada fitur icon/gambar, prinsip effieciency, rating 3, temuan masalah yaitu dibutuhkan waktu 3-4 detik untuk loading gambar pada setiap icon submenu. Misalnya menu pada "Pola Tanam" terdapat 3 submenu, baru dapat menampilkan gambar icon submenu setelah 3 detik. Meskipun ini bergantung pada kecepatan internet yang tersedia, tetapi perlu dipastikan bahwa icon atau gambar yang digunakan tidak berukuran besar, sehingga waktu untuk loading gambar tidak lama. Saran: jangan gunakan foto untuk icon menu dan submenu, tetapi file icon.

- Pada bagian navigasi, prinsip user control and freedom, rating 4 , temuan masalah yaitu tidak ada navigasi untuk kembali/back/previous pada aplikasi, pengguna hanya bisa kembali ke halaman sebelumnya dengan menggunakan "back" pada smartphone.
- Pada fitur masuk dan daftar, prinsip match between system and the real world, rating 3, temuan masalah yaitu pada kedua fitur ini sebenarnya terdapat hyperlink "Masuk di sini" atau "Daftar di sini", tetapi tidak ada tanda pembeda bahwa kedua teks ini adalah hyperlink, bukan teks biasa. Pada fitur Daftar dan Masuk, terdapat penulisan frase yang salah, "disini" seharusnya "di sini". Lakukan pengecekan penulisan kata atau kalimat pada semua halaman aplikasi sehingga tidak ada penulisan yang menyalahi tata tulis bahasa Indonesia.

- Pada fitur daftar, prinsip help users recognize, diagnose, and recovers from errors, rating 3 , temuan masalah yaitu pada kesalahan memasukkan konfirmasi kata sandi, terdapat pesan "Konfirmasi kata sandi salah - Password dan Konfirmasi kata sandi tidak sesuai. Silahkan masukkan kata sandi yang sesuai." Tidak terdapat field PASSWORD" pada saat pendaftaran, hanya ada "Kata Sandi" dan "Konfirmasi Kata Sandi". Pada saat pendaftaran akun, tidak terdapat field untuk mengisi Nama, tetapi saat sudah masuk ke aplikasi, pengguna terdaftar sudah memiliki nama. Dari manakah nama tersebut didapatkan? Terdapat langkah verifikasi akun yang dikirimkan ke email. Cek kembali susunan kalimat, sehingga tidak muncul kalimat tidak dimengerti seperti "Tim Markopi Indonesia Anda". Apakah yang dimaksud dengan "Anda"? Cek kembali semua kalimat. Apakah fungsi verifikasi ini? Karena tanpa itu, sudah bisa menggunakan aplikasi.

- Pada fitur masuk, prinsip consistency and standards, rating 3, temuan masalah yaitu ketika salah memasukkan password, terdapat pesan kesalahan dalam bahasa Inggris.

- Pada fitur Informasiku, prinsip aesthetic and minimalist design, rating 4 , temuan masalah yaitu Layout tidak ditata dengan rapi. Batas antar field, hyperlink, button. Nama user adalah riyanthi. Namun, saat publikasi satu informasi, nama yang tampil adalah by fasilitator. Untuk upload beberapa gambar, langkah terlalu panjang, harus pilih satu gambar, klik navigasi back, lalu pilih gambar lain, tidak bisa sekaligus. Setelah memilih gambar, klik Simpan, tidak ada perubahan/penambahan gambar yang telah dipilih.

- Pada fitur Ubah Profil, prinsip aesthetic and minimalist design, rating 4 , temuan masalah yaitu layout tidak tertata rapi antar komponen. Misalnya "change photo" yang terlalu dekat dengan garis batas "nama anda". Ketika telah klik tombol 
"Ubah Profil", tidak ada aksi kembali ke profil, posisi tetap di halaman sedang mengubah profil.

- Pada semua halaman, prinsip consistency and standards, rating 4, temuan masalah yaitu konsistensi penggunaan bahasa/ istilah pada semua halaman aplikasi. Menggunakan bahasa Indonesia? Sebagian istilah yang sudah familiar di bahasa Inggris tidak diubah ke bahasa Indonesia? Misalnya "change photo", tetapi pada fitur lain "perbaharui gambar". Simulasikan kombinasi warna, tidak didominasi warna hijau yang sama untuk semua halaman.

\section{b. Blackbox Testing}

Blackbox testing dilakukan oleh 3 orang yang merupakan pengembang aplikasi. Pengujian dilakukan terhadap fungsi pada aplikasi yaitu melihat informasi; pencarian informasi; autentikasi; mengelola informasi. Fungsi diuji dengan memberi scenario benar dan salah. Misalnya saat autentikasi, diujicoba untuk memasukkan data yang benar dan data yang hasil. Hasil pengujian menunjukkan bahwa aplikasi memberikan respon yang benar terhadap setiap kondisi yang diuji.

\subsection{Maintenance}

Bagian maintenance merupakan hasil perbaikan berdasarkan hasil heuristic evaluation dan blackbox testing. Hasil akhir berupa aplikasi mobile berbasis Android yang dibangun dapat dilihat pada gambargambar sebagai berikut.

\section{a. Halaman Home}

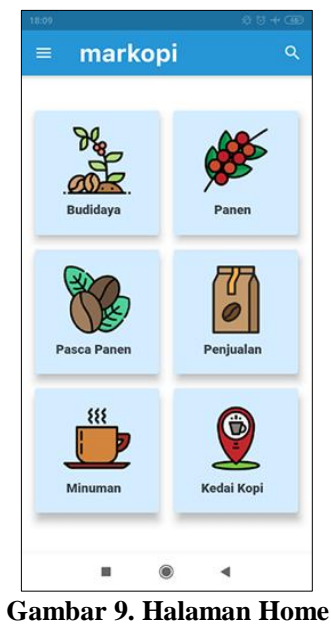

Gambar 9 merupakan tampilan Home aplikasi. Home terdiri dari menu-menu yang ada pada aplikasi.

\section{b. Navigasi}

Gambar 10 merupakan navigasi dimana terdapat menu-menu yang sama dengan halaman Home.

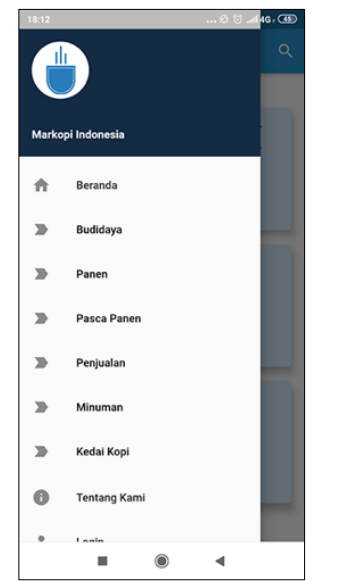

Gambar 10. Halaman Navigasi

c. Halaman Submenu

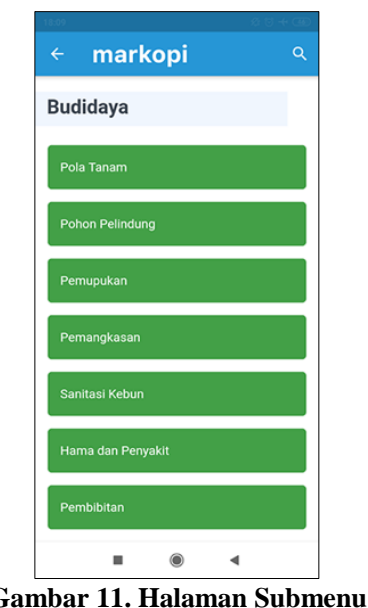

Gambar 11 merupakan halaman submenu pada aplikasi. Jika pengguna memilih salah satu menu pada aplikasi maka akan dialihkan pada halaman submenu tersebut.

d. Halaman Detail Informasi

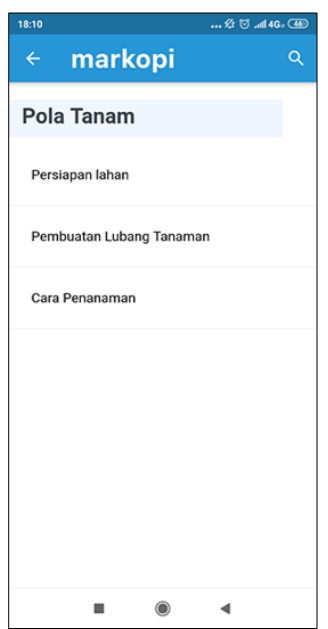

Gambar12. Halaman Detail Informasi 1

Gambar 12 dan Gambar 13 merupakan halaman Detail Informasi, jika sub menu diklik oleh pengguna maka akan muncul seperti pada gambar 
tersebut, dan halaman tersebut merupakan detail atau penjelasan mengenai submenu yang ada.

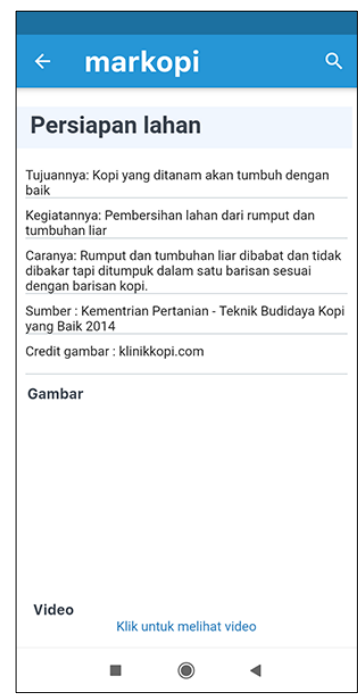

Gambar 13. Halaman Detail Informasi 2

Terdapat beberapa perbedaan rancangan dengan hasil pengembangan aplikasi, misalnya pada halaman Splashscreen menghilangkan gambar untuk mempersingkat waktu loading, pada halaman register menyederhanakan informasi yang perlu dimasukkan oleh pengguna.

\subsection{User Acceptance Test}

Pada kegiatan ini, pengguna menilai kesesuaian dan kelengkapan fungsi-fungsi yang dibutuhkan terhadap aplikasi yang sudah dibangun. Penilaian dilakukan dengan cara pengguna menggunakan aplikasi. Fungsi meliputi melihat informasi, mencari informasi, mendaftar dan masuk ke dalam aplikasi serta update informasi. Hasilnya pengguna menerima dan menyetujui fungsi yang telah disediakan dalam aplikasi.

\section{HASIL}

Hasil yang diperoleh dalam penelitian ini adalah sebuah aplikasi mobile yang menerapkan User Experience Design (UXD). Nama aplikasi ini adalah "Markopi" yang berasal dari Bahasa Batak Toba yang artinya berkopi atau berkebun kopi. Aplikasi ini menyediakan fitur untuk penyediaan informasi bagi petani dan wadah menyebar informasi bagi fasilitator kopi.

Pada penerapan proses User Experience Design dalam pengembangan aplikasi, peneliti telah memperoleh hasil user persona, user stories, user scenario, hasil prototipe, hasil user testing (feedback user dan expert), dan perbaikan yang dilakukan berdasarkan feedback pengguna dan expert. Hasil pengukuran aspek usefulness, ease of use, ease of learning, satisfaction oleh pengguna menunjukkan aplikasi yang dibangun dengan menerapkan UXD berada pada tingkat kegunaan, kemudahan dan kepuasan yang baik.

\section{KESIMPULAN}

Dari penelitian yang dilakukan dapat disimpulkan bahwa penerapan proses User Experience Design (UXD) adalah benar memberi hasil aplikasi yang sesuai dengan kebutuhan pengguna. Hal ini dibuktikan dengan penilaian pengguna pada user testing yang menyatakan sangat setuju pada pemenuhan beberapa aspek User Experience, yaitu usefulness, ease of use, ease of learning dan satisfaction pada aplikasi.

Proses UXD yang memenuhi kebutuhan pengguna diperkuat dengan adanya inspeksi dari usability expert. Hal ini melengkapi pengujian dari sisi pengguna, karena tidak semua masalah usability dapat ditemukan lengkap pada saat user testing. Usability expert melalui kegiatan heuristic evaluation memeriksa kualitas aplikasi dari sisi keilmuan dalam usability, sedangkan pengguna dari segi interaksi dengan aplikasi.

\section{DAFTAR PUSTAKA}

BARNUM, C.M. 2011. Usability Testing Essentials: Reasy, Set...Test!. USA: Elsevier.

BOUCHARD, C. dan BONGARD-BLANCHY, K. 2015. Dimensions of user experience-from the product design perspective, Journal d'Interaction Personne-Système, 3, 1-15.

GETTO, G. 2015, Getting Started with UX Design Process and Documentation.

GREGORY, G dan FEATHERSTONE, A, M. 2008. Nonparametic Efficiency Analysis for Coffee Farms in Puerto Rico, Southern Agricultural Economics Association Annual Meeting.

HARTSON, R. dan PYLA, P. 2012. The UX Book: Process and Guidelines for Ensuring a Quality User Experience. Waltham: Elsevier.

Interaction Design Foundation (IDF). 2018. The Basics of User Experience Design.

MORVILLE, P. 2004. User Experience Design. USA: Semantic Studios.

ORLOVA, M. 2016. User Experience Design (UX Design) In a Website Development Website Redesign, December.

SUGIYONO. 2010. Metode Penelitian Pendidikan: Pendekatan Kuantitatif, Kualitatif dan R\&D. Bandung.

UNGER, R dan CHANDLER, C. 2012. A Project Guide to UX Design, Second Edition. United States of America: New Riders. 